\title{
POLYMORPHISM OF TISSUE INHIBITORS OF METALLOPROTEINASE-2 (G303 $\rightarrow$ A) GENE IN PATIENTS WITH INTESTINAL ANASTOMOTIC LEAK IN UKRAINIAN POPULATION
}

\section{Y. Y. Voitiv}

Shupyk National Healthcare University of Ukraine, Kyiv, Ukraine

Purpose - to analyze the frequency of polymorphic variants of tissue inhibitors of metalloproteinase-2 $\left(G^{303} \rightarrow\right.$ A) gene in patients with intestinal anastomotic leak.

Material and methods. The object of the study comprises 61 patients with anastomotic leak and connective tissue pathology, who were treated in the department of thoracoabdominal surgery of Shalimov National Institute of Surgery and Transplantology during 20172020. Laboratory, genetic, histological studies and statistical analysis were performed.

Results. As a result of genetic and statistical analysis of the tissue inhibitors of metalloproteinase-2 $\left(G^{303} \rightarrow\right.$ A) gene polymorphisms, genotype variants have been identified that are associated with the risk of anastomotic leak in the hollow digestive organs. Significant differences in the distribution of genotypes in the studied groups were revealed. Analysis of the multiplicative model of inheritance of tissue inhibitors of metalloproteinase-2 $\left(G^{303} \rightarrow A\right)$ gene showed compliance of genotype distribution with Hardy-Weinberg's law. All models of inheritance were analyzed and the best model with the lowest Akaike Information Criterion, which turned out to be a recessive model, has been determined.

Conclusions. It is statistically significant that in the group of patients with intestinal anastomotic leak the GG variant of the TIMP-2 gene was detected in 1,6 times more often. Carriers of minor homozygotes of AA genotype in the group with suture failure were not detected, while a similar genotype in the control group was found in $10 \%$ $(p<0,05)$.

\section{ПОЛІМОРФІЗМ ГЕНА ТКАНИННОГО ІНГІБІТОРА МАТРИКСНОӤ МЕТАЛОПРОТЕЇНАЗИ-2 $\left(\mathrm{G}^{303} \rightarrow\right.$ А) У ХВОРИХ ІЗ НЕСПРОМОЖНІСТЮ КИШКОВИХ ШВІВ В УКРАЇНСЬКІЙ ПОПУЛЯЦЇ̈}

\section{Я.Ю. Войmiв}

Мета дослідження: провести аналіз частоти поліморфних варіантів гена тканинного інгібітора матриксної металопротеїнази-2 $\left(G^{303} \rightarrow\right.$ A) у хворих із неспроможністю швів міжкишкових анастомозів в української популяиії.

Матеріал і методи. Об'єктом дослідження був 61 пацієнт з неспроможністю швів анастомозів і патологією сполучної тканини, які лікувалися в ДУ «НІХТ ім. А.А. Шалімова». Проведені лабораторні, генетичні, гістологічні та статистичні дослідження.

Результати. У результаті генетичного і статистичного аналізу поліморфізму гена тканинного інгібітора матриксної металопротеїнази-2 (G $G^{303} \rightarrow$ A) були визначені варіанти генотипів, асочійованих із ризиком розвитку неспроможності швів кишкових анастомозів. Виявлено достовірні відмінності розподілу генотипів у досліджуваних групах. Аналіз мультиплікативної моделі успадкування гена тканинного інгібітора матриксної металопротеїнази-2 $\left(G^{303} \rightarrow\right.$ A) показав відповідність розподілу генотипів закону Харді-Вайнберга. Проаналізовано всі спадкові модел, і визначена найкращуа модель із найбільш низьким інформаційним критерієм Айкайке, якою виявилась рецесивна модель.

Висновки. У групі пацієнтів із неспроможністю швів міжкишкових анастомозів статистично достовірно, в 1,6 раза частіше, виявлено носїв гомозиготного $G G$ варіанта гена тканинного інгібітора матриксної металопротеїнази-2 $\left(G^{303} \rightarrow A\right)$. Носіїв мінорних гомозигот АА генотипу в групі з неспроможністю швів виявлено не було, тоді як аналогічний генотип у контрольній групі траплявся в $10 \%(p<0,05)$.
Key words: Anastomotic leak, TIMP-2, gene polymorphism.

Clinical and experimental pathology 2021. Vol.20, №1 (75). P.87-92.

DOI:10.24061/1727-4338. XX.1.75.2021.13

E-mail: voitiv.yaroslav@gmail. com

\section{Ключові слова:} неспроможність кишкових анастомозів, тканинний інгібітор матриксної металопротеінази-2, поліморфізм генів.

Клінічна та експериментальна патологія 2021. T.20, №1 (75). C.87-92.
Ключевые слова: несостоятельность кимечных анастомозов, тканевой ингибитор матриксной металлопро- 
теиназы-2, полиморфизм генов.

Клиническая и экспериментальная патология 2021. Т.20, №1 (75).

C.87-92.
Цель - провести анализ частоты полиморфных вариантов гена тканевого ингибитора матриксной металлопротеиназы-2 $\left(G^{303} \rightarrow A\right)$ у больных $c$ несостоятельностью швов анастомозов польх органов пищеварения украинской популяции.

Материал и методы. Объектом исследования был 61 пациент с несостоятельностью швов анастомозов и патологией соединительной ткани, которые лечились в ГУ «НИХТ им. А.А. Шалимова». Проведены лабораторные, генетические, гистологические и статистические исследования.

Результаты. В результате генетического и статистического анализа полиморфизма гена тканевого ингибитора матриксной металлопротеиназь-2 $\left(G^{303} \rightarrow A\right)$ были определены варианты генотипов, ассоциированных с риском развития несостоятельности швов кишечных анастомозов. Выявлены достоверные различия распределения генотипов в группах, которые изучались. Анализ мультипликативной модели наследования гена тканевого ингибитора матрикснойметаллопротеиназы-2 $\left(G^{303} \rightarrow\right.$ A) показал соответствие распределения генотипов с законом Харди-Вайнберга. Проанализированы все наследственные модели и определена лучшая модель с наиболее низким информационным критерием Айкайке, которой оказалась рецессивная модель.

Выводы. В группе пациентов с несостоятельностью швов анастомозов польх органов пищеварения статистически достоверно, в 1,6 раза чаще, выявлено носителей гомозиготного GG варианта гена тканевого ингибитора матриксной металлопротеиназы-2 (G $G^{303} \rightarrow$ A). Носителей минорных гомозигот АA генотипа 8 группе с несостоятельностью швов обнаружено не было, тогда как аналогичный генотип в контрольной группе встречался в $10 \%(p<0,05)$.

\section{Introduction}

Despite the improvement of existing techniques and the development of new surgical technologies, the anastomotic leak in the hollow digestive organs is one of the most difficult complications in abdominal surgery. The incidence of such complications, according to various authors, ranges from $2-8.1 \%$ in small bowel anastomosis to $3.8-14.6 \%$ in operations on the colon [12]. Anastomotic leak is accompanied by mortality rate of $14-21,7 \%$ [3]; with the development of disseminated peritonitis, abdominal sepsis mortality increases up to $43-82,9 \%[1,4]$. So far, there is no single point of view in the surgical community regarding the causes of anastomotic leak development and surgical tactics in the development of these complications. According to the literature on the subject, among the risk factors for the development of an anastomotic leak are microcirculation disruption in the anastomosis area, tissue regeneration failure, infection, increased intra-intestinal pressure, changes in the rheological properties of blood, homeostatic imbalances, etc. [1]. A separate group of risk factors includes tactical and technical errors in the formation of anastomosis [5].

Although there is no doubt about the role of regenerative processes in the formation of intestinal anastomosis [6,7], scientific publications and research at the current methodological level on this topic are not enough. An in-depth study of the mechanisms of reparative regeneration in the area of the anastomosis and possibilities of the regenerative processes stimulation, adequate restoration of morpho-functional characteristics of digestive organs that have been anastomosed is necessary. In domestic and foreign sources, there are almost no publications about the role of undifferentiated dysplasia of the connective tissue (UDCT) in the development of anastomotic leak in the hollow digestive organs.
Given the almost unexplored role of genetic predisposition in the development of postoperative complications, namely the failure of anastomotic sutures, we set a goal to study the polymorphism of gene encoding tissue inhibitor of matrix metalloproteinase-2 (TIMP-2). The choice of these genes was not accidental - we were guided by the main known pathophysiological mechanisms involved in the formation of the intestinal anastomosis [7].

The main regulators of matrix metalloproteinases (MMP) are tissue inhibitors of metalloproteinases TIMPs (TIMP-1, TIMP-2, TIMP-3, TIMP-4). All 4 groups of TIMPs can inhibit the proteolysis of the latent forms of MMP and inhibit the active forms of MMP, but TIMP-1 is more active against MMP-9, and TIMP-2 shows specificity for MMP-2 [8].

At the same time, information on the role of TIMPs in the development of intestinal anastomotic leak is almost absent. However, we have not found publications on the study of genetic polymorphism of TIMPs of the development of anastomotic leak.

\section{The aim of research}

To analyze the frequency of polymorphic variants of gene TIMP-2 $\left(\mathrm{G}^{303} \rightarrow \mathrm{A}\right)$ in patients with intestinal anastomotic leak.

\section{Material and methods}

A retro- and prospective trial was based on data of 61 patients, who were treated at the Shalimov National Institute of Surgery and Transplantology. 17 of 61 patients (experimental group 2) suffered anastomotic leak in hollow digestive organs, 44 of 61 patients (experimental group 1) had phenotypic signs of UDCT. For the assessment of genetic polymorphism in the population, 80 practically healthy people (Ukrainian population) have been examined (control group), who

Клінічна та експериментальна патологія. 2021. Т.20, № 1 (71) 
were matched by gender and age with experimental groups. For the assessment of connective tissue, we analyzed free hydroxyproline in the serum and urinary glycosaminoglycans. UDCT has been diagnosed with a proven technique (Ukrainian patent for utility model №120158 UA). The stage of dysplasia was evaluated using the original clinical screening scale, which was based on the table of the severity criteria of connective tissue dysplasia made by T.Y. Smolnova (2003) [9].

Genetic studies were performed in the laboratory of the Department of General and Molecular Pathophysiology at the Bogomoletz Institute of Physiology NAS of Ukraine. The collection of the buccal epithelium was performed using buccal brushes with the upcoming freezing of the samples at the temperature of $-20^{\circ} \mathrm{C}$. DNA for the genotyping was extracted from the samples using Diatom ${ }^{\mathrm{TM}}$ Prep 200 (Isogen Laboratory, RF) following the manufacturer's protocol.

The following polymorphisms were studied by real-time PCR: G $^{303} \rightarrow$ A (TIMP2), rs9900972. Amplification reactions were performed using the Fast Real-time PCR System (Applied Biosystems, USA) in a final reaction volume of $20 \mu$ containing 2 X TaqMan Universal Master Mix (Applied Biosystems, USA), assay C_1792560_10 and template DNA. Amplification of gene fragments consisted of a denaturation step at $95^{\circ} \mathrm{C}$ for $20 \mathrm{~s}$, followed by 40 cycles of amplification at $95^{\circ} \mathrm{C}$ for $3 \mathrm{~s}$ and $60^{\circ} \mathrm{C}$ for $30 \mathrm{sec}$. Data analysis was performed with 7500 Fast Real-Time PCR Software (Applied Biosystems, Foster City, USA).

The main part of the statistical analysis was performed using the program "Statistica 7.0" (SPSS) and Excel 2000. Nominal data were presented in the form of quantitative and percentage values. The significance of differences in mean values in groups with different genotypes was determined using the method of one-way analysis of variance (URL: http://www.dgmp.kyiv.ua/ index.php/snip-ka). The correspondence of genotype distribution was checked using the Hardy-Weinberg test. Pearson's $\chi^{2}$ test was used to compare the distribution of genotypes in the experimental and control groups.

\section{Results and discussion}

To identify the possible association of polymorphic variants of TIMP2 $\left(\mathrm{G}^{303} \rightarrow\right.$ A) gene with the risk of anastomotic leak, we performed a one-way analysis of variance of the frequency of genotypes in the studied groups of patients (Table 1).

Table 1

The distribution of polymorphic variants of gene TIMP-2 $\left(G^{303} \rightarrow A\right)$, rs9900972 in the studied groups

\begin{tabular}{|c|c|c|c|c|}
\hline \multicolumn{2}{|c|}{ The studied gene } & $\begin{array}{c}\text { Control group } \\
\mathrm{n}=80(\%)\end{array}$ & $\begin{array}{c}\text { Experimental group 1 } \\
\text { (with phenotypic signs } \\
\text { of UDCT) } \\
\mathrm{n}=44(\%)\end{array}$ & $\begin{array}{c}\text { Experimental group 2 } \\
\text { (with anastomotic } \\
\text { leak) } \\
\mathrm{n}=17(\%)\end{array}$ \\
\hline \multirow{2}{*}{$\begin{array}{c}\text { TIMP2 } \\
\left(\mathrm{G}^{303} \rightarrow \mathrm{A}\right)\end{array}$} & GG & $50(50 \%)$ & $24(54,5 \%)$ & $14(82,4 \%)$ \\
\cline { 2 - 5 } & GA & $32(40 \%)$ & $15(34,1 \%)$ & $3(17,6 \%)$ \\
\hline \multicolumn{2}{|c|}{ Hardy-Weinberg test $\left(\chi^{2}, \mathrm{p}\right)$} & $8(10 \%)$ & $5(11,4 \%)$ & $0(\%)$ \\
\hline
\end{tabular}

In the analysis of TIMP-2 inheritance models $\left(\mathrm{G}^{303} \rightarrow\right.$ A), in the control group $(\mathrm{n}=80)$ and experimental group 1 with phenotypic signs of connective tissue pathology $(n=44)$, we could not find statistically significant differences in the distribution of genotypes in the group of patients and the group of almost healthy people ( $p>0,05)$. The conformity of the genotype distribution to Hardy-Weinberg's law in the control group was checked using the $\chi^{2}$ test with 1 degree of freedom, without Yates correction use. It has been found that the distribution of genotypes in the control group corresponds to Hardy-Weinberg's law ( $>00,05)$. We were able to find statistically significant differences in the distribution of genotypes $(p<0,05)$ in the analysis of TIMP-2 inheritance models $\left(\mathrm{G}^{303} \rightarrow\right.$ A), in the control group $(\mathrm{n}=80)$ and experimental group 2 with anastomotic leak $(n=17)$. The conformity of the genotype distribution to Hardy-Weinberg's law in the control group was checked using the $\chi^{2}$ test with 1 degree of freedom, without the use of Yates correction. After analyzing all models of inheritance, we chose the best model with the lowest AIC (Table 2).

The odds ratio for recessive inheritance model in patients with anastomotic leak.

Table 2 Odds ratio with $95 \%$ confidence interval.

\begin{tabular}{|c|c|c|c|c|c|}
\hline Genotype & $\begin{array}{c}\text { Control group } \\
\mathrm{n}=80(\%)\end{array}$ & $\begin{array}{c}\text { Experimental group 2 (with } \\
\text { anastomotic leak) } \mathrm{n}=17(\%)\end{array}$ & Odds ratio & -value & AIC \\
\hline GG+GA & $72(90 \%)$ & $17(100 \%)$ & 1.00 & & \\
\hline AA & $8(10 \%)$ & $0(0 \%)$ & $0(\mathrm{NA}-1.479 \mathrm{e}+266)$ & 1 & 15.62 \\
\hline
\end{tabular}


In the examined population in the control group and experimental group 1, the distribution of carriers of GG, GA, and AA genotypes was significantly similar. However, in the group of patients with anastomotic leak (experimental group 2), the distribution of genotype carriers was significantly different. Thus, the dominant GG variant almost twice significantly exceeded the indicators of control and experimental group $1(82,4 \%$ vs. $50 \%$ and $54,4 \%$, respectively, $\mathrm{p}<0,05)$. Heterozygous GA genotype in the second experimental group was more than twice as rare as in the control (17,6\% vs. $40 \%)$. Carriers of homozygous AA genotype in the group with anastomotic leak were not detected, while a similar variant in control and experimental group 1 was found in $10 \%$ and $11,4 \%$ of cases (Diagram 1 ).

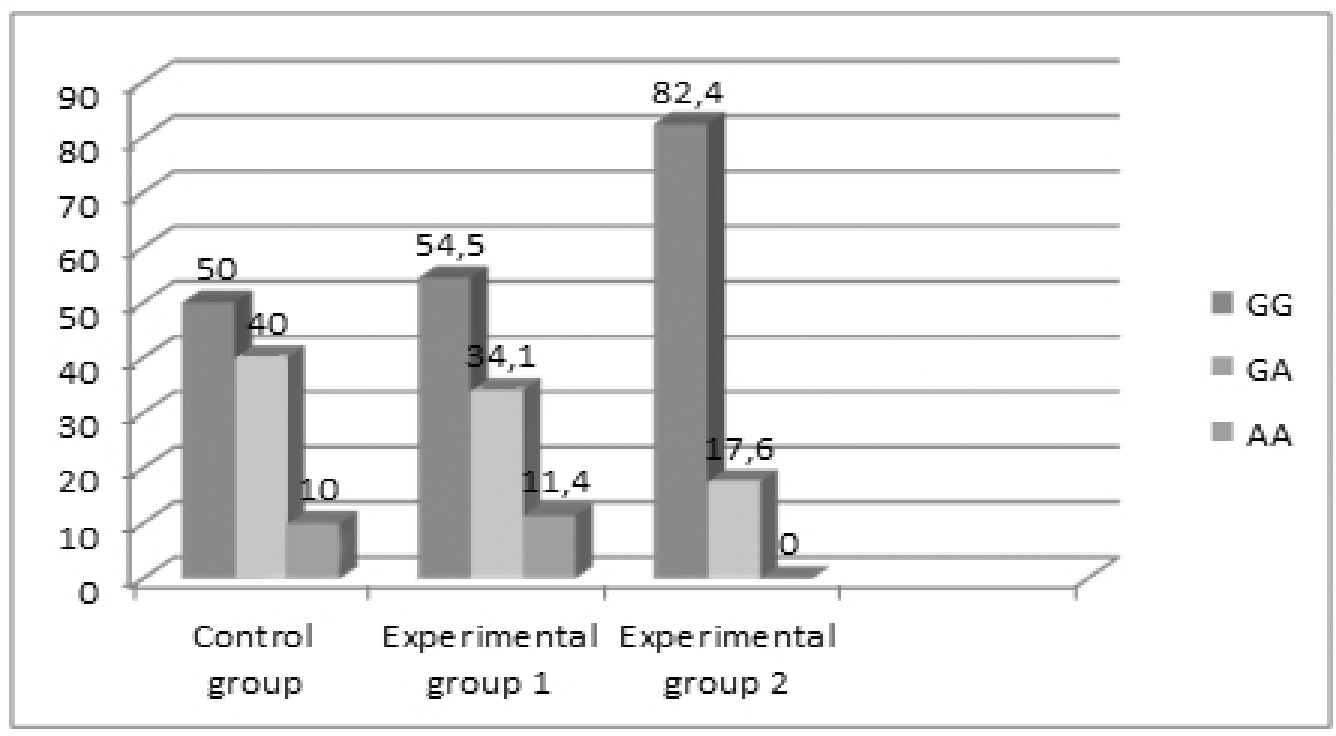

Diagram 2. Frequency distribution of allelic polymorphism $(\%)$ of the promoter $\left(G^{303} \rightarrow A\right)$ of the TIMP2 gene

In the examined patients with anastomotic leak of the hollow digestive organs, signs of UDCT were found in 13 $(76,47 \%)$ patients. The following phenotypic pathologies of UDCT were most commonly encountered: visceral pathology $(76,47 \%)$, vascular pathology (70,58\%), arrhythmias $(52,9 \%)$.

The study of phenotypic signs of UDCT in the group of patients with anastomotic leak showed that 3 patients $(17,6 \%)$ had a mild UDCT, 6 patients $(35,3 \%)$ had moderate, and 4 patients $(23,6 \%)$ had a severe degree of UDCT. In 4 patients $(23,5 \%)$, signs of the pathology of the connective tissue were not detected.

The level of serum hydroxyproline in the group of patients without phenotypic signs of connective tissue dysplasia was $36,9 \pm 1.6 \mu \mathrm{mol} / \mathrm{L}$, which is almost twice as high as in the control group $(21,2 \pm 0.8 \mu \mathrm{mol} / \mathrm{L})$. When studying the dynamics of changes in serum hydroxyproline levels, it was found that an increase in the collagenolytic activity of glycosaminoglycans and free hydroxyproline levels had a direct correlation with the severity of UDCT. With a mild degree of UDCT, the level of serum hydroxyproline was $(46,9 \pm 2,8) \mu \mathrm{mol} / \mathrm{L}$, moderate $(75,2 \pm 3.2) \mu \mathrm{mol} / \mathrm{L}$ and severe $(122,1 \pm 3.6)$ $\mu \mathrm{mol} / 1$, which is almost 6 times higher than in the control group and 3 times higher than in patients with anastomotic leak without clinical signs of connective tissue dysplasia.

When studying the dynamics of changes in urinary glycosaminoglycans levels, a direct correlation with the severity of UDCT was also revealed. With a mild degree of UDCT, the level of glycosaminoglycans was $80,94 \pm 2.8 \mu \mathrm{mol} / \mathrm{L}$, which is highly reliable, twice as many as in the control group $(44,68 \pm 1.8)$. With an average degree of $105,12 \pm 3.5 \mu \mathrm{mol} / \mathrm{L}$ and a severe degree of $127,54 \pm 3,4 \mu \mathrm{mol} / \mathrm{L}$, which was almost 3 times higher than the control group and 2 times higher than patients with anastomotic leak without clinical signs of connective tissue dysplasia.

Our data on the study of polymorphic variants of the TIMP2 $\left(\mathrm{G}^{303} \rightarrow \mathrm{A}\right)$ gene in the Ukrainian population $(n=80)$ generally correspond to populations of Europe and the USA $[10,11]$.

The closest genotypic variations in the studied genes were populations of Austria [12] and the Netherlands [13]. Moreover, we found significant differences when compared with the African and Asian populations [14, 15].

As a result of genetic and statistical analysis of the polymorphism of the TIMP-2 $\left(\mathrm{G}^{303} \rightarrow \mathrm{A}\right)$ gene, variants of genotypes associated with the risk of development of anastomotic leak of the hollow digestive organs were determined.

In the analysis of carriers of TIMP-2 genotypes, we obtained statically reliable data: in the group of patients with anastomotic leak, GG variant was $82,4 \%$, which is 1.6 times higher than in the control group $(82,4 \%$ vs. $54,4 \%, p<0,05)$. Carriers of minor homozygotes of AA genotype in the group of patients with anastomotic leak were not detected, while a similar genotype in the control group was found in $10 \%$.

Given the role of matrix metalloproteinases and their inhibitors in the processes of synthesis and proteolysis, 
connective tissue remodeling, connective tissue protein metabolism, the ability to affect vascular permeability and angiogenesis, the relevance of their study in the context of the pathogenesis of anastomotic leak of the hollow digestive organs is undoubted.

The correlation between the level of biochemical markers of collagen biodegradation and the severity of UDST have been revealed, which is diagnosed on the basis of phenotypic, visceral manifestations, and instrumental examinations. This could serve as an informative diagnostic criterion of UDST and could be used to predict the development and course of complications in patients with anastomotic leak in the hollow digestive organs. Such changes are apparently due to increased proteolytic activity in patients with anastomotic leak. This confirms the data of some authors that the anastomotic leak and development of peritonitis leads to a pronounced and persistent mismatch in the proteinase system - inhibitors of blood proteinases. It is the hyperactivation of proteolytic systems of the body against a background of reduction of inhibitory potential that is regarded as one of the key pathogenetic links of endogenous intoxication.

Understanding the pathogenetic processes underlying the formation of the anastomosis and possible "weaknesses" is no less important than the surgical technique [16].

In our view, the focus of future research on the pathogenetic factors of abdominal postoperative complications should be shifted to a more cellular and molecular level. Thus, a better understanding of the mechanisms of the formation of intestinal anastomosis will contribute to the development of new diagnostic, prognostic, and therapeutic techniques.

The differences we have identified in allelic variants of the studied genes in the groups with anastomotic leak are the basis for further study and research for molecular genetic markers that encode the main links in the pathogenesis of anastomotic leak and other postoperative complications.

\section{Conclusions}

1.In the group of patients with anastomotic leak in the hollow digestive organs, it is statistically significant, the GG variant of the TIMP-2 gene was detected 1.6 times more often. Carriers of minor homozygotes of AA genotype in the group with anastomotic leak were not detected, while a similar genotype in the control group was found in $10 \%$ $(\mathrm{p}<0,05)$.

2.Molecular genetic research can be a new promising area for the development of modern personalized diagnostic criteria and models for predicting the development and course of postoperative abdominal complications, including the intestinal anastomotic leak.

3.The presence of connective tissue dysplasia in patients with intestinal anastomotic leak is an aggravating comorbid factor, which must be considered when choosing adequate surgical tactics and complex pathogenetically substantiated treatment.

\section{Prospects for further research}

The identified features of allelic variants of the TIMP2 gene $\left(\mathrm{G}^{303} \rightarrow \mathrm{A}\right)$ in groups of patients with external intestinal fistulas are the basis for further study and search for molecular genetic markers encoding the main links in the pathogenesis of abdominal postoperative complications.

\section{Literature:}

1. Бойко ВВ, Лєонов АВ, Тарабан IA, Логачев ВК, Леонов BВ. Неспроможність кишкових анастомозів. Харківська хірургічна школа. 2013;(6):5-8

2. Шальков ЮЛ, Леонов ВВ. Кишечные швы и анастомозы в хирургической практике. Харьков: Коллегиум; 2008. 191 с.

3. Pitel S, Lefèvre JH, Tiret E, Chafai N, Parc Y. Redo coloanal anastomosis: a retrospective study of 66 patients. Ann Surg. 2012;256(5):806-10. doi: 10.1097/sla.0b013e318272de70

4. de Zeeuw S, Ali UA, Donders RART, Hueting WE, Keus F, van Laarhoven CJHM. Update of complications and functional outcome of the ileo-pouch anal anastomosis: overview of evidence and meta-analysis of 96 observational studies. Int $\mathrm{J}$ Colorectal Dis. 2012;27(:843-53. doi: 10.1007/s00384-011-1402-6

5. Мельник ВM, Пойда ОI. Хірургічна тактика при неспроможності швів міжкишкових анастомозів. Клінічна хірургія. 2016;(6):8-12.

6. Алексеева НТ, Глухов АА, Остроушко АП. Роль фибропластических клеток в заживлении ран. Вестник экспериментальной и клинической хирургии. 2012;5(3):601-

7. Marjanovic G, Hopt UT. Physiologie der Anastomosenheilung. Chirurg. 2011;82(1):41-7. doi: $10.1007 /$ s00104-010-1898-2

8. Fassina G, Ferrari N, Brigati C, Benelli R, Santi L, Noonan $\mathrm{DM}$, et al. Tissue inhibitors of metalloproteases: Regulation and biological activities. Clin Experim Metastas. 2000;18(2):111-20. doi: 10.1023/a:1006797522521

9. Усенко ОЮ, Войтів ЯЮ. Частота та критерії діагностики недиференційованої дисплазії сполучної тканини у хворих хірургічного стаціонару. Клінічна хірургія. 2017;10:5-7. doi: $10.26779 / 2522-1396.2017 .10 .05$

10. National Center for Biotechnology Information. Reference SNP (rs) Report. rs243865 [Internet]. 2020[cited 2021 Apr 10]. Available from: https://www.ncbi.nlm.nih.gov/snp/rs243865

11. National Center for Biotechnology Information. Reference SNP (rs) Report. Rs9900972 [Internet]. 2020[cited 2021 Apr 10]. Available from: https://www.ncbi.nlm.nih.gov/snp/rs9900972

12. Mossbock G. Weger M. Faschinger C. Zimmermann C. Schmut O. Renner W, et al. Role of functional single nucleotide polymorphisms of MMP1, MMP2, and MMP9 in open angle glaucomas. Mol Vis. 2010;(16):1764-70.

13. van Diemen CC. Postma DS. Siedlinski M. Blokstra A. Smit HA. Boezen HM. Genetic variation in TIMP1 but not MMPs predict excess FEV1 decline in two general population-based cohorts. Respir Res [Internet]. 2011[cited 2021 Apr 19];12(1):57. Available from: https://www.ncbi.nlm.nih.gov/pmc/articles/PMC3111362/ pdf/1465-9921-12-57.pdf doi: 10.1186/1465-9921-12-57

14. Xu E, Lai M, Lv B, Xing X, Huang Q, Xia X. A single nucleotide polymorphism in the matrix metalloproteinase-2 promoter is associated with colorectal cancer. Biochem Biophys Res Commun. 2004;324(3):999-1003. doi: 10.1016/j.bbrc.2004.09.150

15. Li Y, Sun DL, Duan YN, Zhang XJ, Wang N, Zhou RM, et al. Association of functional polymorphisms in MMPs genes with 
gastric cardia adenocarcinoma and esophageal squamous cell carcinoma in high incidence region of North China. Mol Biol Rep. 2010;37(1):197-205. doi: 10.1007/s11033-009-9593-4

16. Voitiv YY, Usenko OY, Dosenko VY, Dyadyk OO, Valikhnovska KG, Dzhemiliev A. Genetic and morphological aspects of intestinal anastomotic leak development. Medical Science. 2020;24(106):4278-85.

\section{References}

1. Boyko VV, Leonov AV, Taraban IA, Logatchev VK, Leonov VV. Nespromozhnist' kyshkovykh anastomoziv [Incapacity of intestinal anastomoses]. Kharkiv surgical school. 2013;(6):5-8. (in Ukrainian)

2. Shal'kov YuL, Leonov VV. Kishechnye shvy i anastomozy v khirurgicheskoy praktike [Intestinal sutures and anastomoses in surgical practice]. Khar'kov: Kollegium; 2008. 191 p. (in Russian)

3. Pitel S, Lefèvre JH, Tiret E, Chafai N, Parc Y. Redo coloanal anastomosis: a retrospective study of 66 patients. Ann Surg. 2012;256(5):806-10. doi: 10.1097/sla.0b013e318272de 70

4. de Zeeuw S, Ali UA, Donders RART, Hueting WE, Keus F, van Laarhoven CJHM. Update of complications and functional outcome of the ileo-pouch anal anastomosis: overview of evidence and meta-analysis of 96 observational studies. Int J Colorectal Dis. 2012;27(:843-53. doi: 10.1007/s00384-011-1402-6

5. Mehlnyk VM, Poyda OI. Khirurhichna taktyka pry nespromozhnosti shviv mizhkyshkovykh anastomoziv [Surgical tactics in insufficiency of the interintestinal anastomoses sutures]. Klinichna khirurhiia. 2016;(6):8-12. (in Ukrainian)

6. Alekseeva NT, Glukhov AA, Ostroushko AP. Rol' fibroplasticheskikh kletok $\mathrm{V}$ zazhivlenii ran [The role of fibroplastic cells in wound healing]. Vestnik eksperimental'noy i klinicheskoy khirurgii. 2012;5(3):601-8. (in Russian)

7. Marjanovic G, Hopt UT. Physiologie der Anastomosenheilung. Chirurg. 2011;82(1):41-7. doi: 10.1007/ s00104-010-1898-2

8. Fassina G, Ferrari N, Brigati C, Benelli R, Santi L, Noonan
DM, et al. Tissue inhibitors of metalloproteases: Regulation and biological activities. Clin Experim Metastas. 2000;18(2):111-20. doi: 10.1023/a:1006797522521

9. Усенко ОЮ, Войтів ЯЮ. Частота та критерії діагностики недиференційованої дисплазії сполучної тканини у хворих хірургічного стаціонару [The rate and criteria of diagnosis of undifferentiated dysplasia of connective tissue in stationary patients]. Klinichna khirurhiia. 2017;10:5-7. doi: 10.26779/25221396.2017.10.05 (in Ukrainian)

10. National Center for Biotechnology Information. Reference SNP (rs) Report. rs243865 [Internet]. 2020[cited 2021 Apr 10]. Available from: https://www.ncbi.nlm.nih.gov/snp/rs243865

11. National Center for Biotechnology Information. Reference SNP (rs) Report. Rs9900972 [Internet]. 2020[cited 2021 Apr 10]. Available from: https://www.ncbi.nlm.nih.gov/snp/rs9900972

12. Mossbock G. Weger M. Faschinger C. Zimmermann C. Schmut O. Renner W, et al. Role of functional single nucleotide polymorphisms of MMP1, MMP2, and MMP9 in open angle glaucomas. Mol Vis. 2010;(16):1764-70.

13. van Diemen CC. Postma DS. Siedlinski M. Blokstra A. Smit HA. Boezen HM. Genetic variation in TIMP1 but not MMPs predict excess FEV1 decline in two general population-based cohorts. Respir Res [Internet]. 2011 [cited 2021 Apr 19];12(1):57. Available from: https://www.ncbi.nlm.nih.gov/pmc/articles/PMC3111362/ pdf/1465-9921-12-57.pdf doi: 10.1186/1465-9921-12-57

14. Xu E, Lai M, Lv B, Xing X, Huang Q, Xia X. A single nucleotide polymorphism in the matrix metalloproteinase-2 promoter is associated with colorectal cancer. Biochem Biophys Res Commun. 2004;324(3):999-1003. doi: 10.1016/j.bbrc.2004.09.150

15. Li Y, Sun DL, Duan YN, Zhang XJ, Wang N, Zhou RM, et al. Association of functional polymorphisms in MMPs genes with gastric cardia adenocarcinoma and esophageal squamous cell carcinoma in high incidence region of North China. Mol Biol Rep. 2010;37(1):197-205. doi: 10.1007/s11033-009-9593-4

16. Voitiv YY, Usenko OY, Dosenko VY, Dyadyk OO, Valikhnovska KG, Dzhemiliev A. Genetic and morphological aspects of intestinal anastomotic leak development. Medical Science. 2020;24(106):4278-85.

\section{Відомості про авторів:}

Войтів Я.Ю. - к.мед.н., доцент кафедри хірургії та трансплантології Національного медичного університету охорони здоров'я імені П.Л. Шупика, м. Київ, Україна orcid.org/0000-0003-2638-9352

\section{Сведения об авторах:}

Войтив Я.Ю. - к.мед.н., доцент кафедры хирургии и трансплантологии Национального университета здравоохранения имени П.Л. Шупыка, г. Киев, Украина

\section{Information about the authors:}

Voitiv Yaroslav Yu. - MD, PhD (Med), Associate Professor, Shupyk National Healthcare University of Ukraine, Kyiv, Ukraine 